International Journal of

Emerging Multidisciplinary Research

\title{
Standardization of Broadcasting Language Practices for International Comparability and Applicability
}

\author{
Analiza Acuña-Villacorte ${ }^{1}$ \\ ${ }^{1}$ Bulacan State University, City of Malolos Bulacan, Philippines, 3000
}

\begin{abstract}
Background/Objectives: The refinement of knowledge in broadcasting language requires a precise distinction between comparability and applicability. Methods/Statistical analysis: The similarities and differences in the language practices - the comparability, and the relevance of language practices- applicability, regulation of the process, and the impact of the attitude exhibited by the trainees in the workplace; are the main concerns of the language learning. Findings: This study hoped to standardize the broadcasting language practices of Bulacan State University (BSU) BA Broadcasting graduating students in the Philippines by determining the level of the international comparability and applicability of the attributes in broadcasting language. Improvements/Applications: The international competitiveness of any education program is dependent on competence and performance which demand careful planning, effective program implementation, appropriate learning opportunities, and fitted evaluation scheme.
\end{abstract}

\section{Index Terms}

Standardization, Broadcasting language, International competitiveness

\footnotetext{
Corresponding author : Analiza Acuña-Villacorte

analizavillacorte@yahoo.com

- Manuscript received July 9, 2017.

- Revised July 31, 2017; Accepted September 1, 2017.

- Date of publication September 30, 2017.

(c) The Academic Society of Convergence Science Inc.

2546-1583 $\odot 2017$ IJEMR. Personal use is permitted, but republication/redistribution requires IJEMR permission.
} 


\section{INTRODUCTION}

The popularity of the use of the over the air (OTA) distribution of information to a dispersed target audiences has evolved extensively from the transmission of message using wireless telegraphy in Europe to direct broadcasting satellite in the USA. In 2015 , the radio at $93 \%$ listenership and television at $85 \%$ viewership marked the lead reach platforms over the air waves against the use of PC, smartphone use, and tablet use; also in the same year, Pew State of the News Media reported that the traditional $\mathrm{AM} / \mathrm{FM}$ continues to reach the majority of the American public audio (www.pewresearch.org). Only two billion are adult smartphone users around the world, despite the improvement in its infrastructure- faster downloads and lower data charges (www.economist.com). It can be inferred that with the $86 \%$ adult population of the 7 billion population of the world (www.indexmundi.com), the majority of the listeners and viewers are adults. These facts may mean that the future of the broadcast technology may still be very promising. Thus the demand for information market will continue to be competitive.

The influence of media has become critical in the formation of the society and in continuously growing gaps between the technology and the values of the society particularly the youth's. However crucial in the performance of its role, still, the number of research conducted about media were mainly concerned on the safe broadcasting[1] UK audience attitudes to the broadcast media (www.ofcom.org.uk); audience research: effects analysis (www.museum.tv); the cultivation of the effects of TV broadcasting and online media [2]; digital audio broadcasting: principles and applications of DAB [3]; problems related to broadcasting in graphs [4]; all of which are focused either on the system or the impact of the end results, but never on the production, the attributes of the producers, and the role of language in achieving the ultimate goals of OTA- instruction, education, commercial, and interdependence.

This evaluation of the language practices of the Bachelor of Arts in Broadcasting in Bulacan State University Philippines described the correlation of the language competence of the graduating students in the classroom and in the industry during the OJT, and the attributes of the graduates as an indicator of their international competitiveness.

Thus, the study proved that the refinement of knowledge in broadcasting language requires a precise distinction between the comparability or the impact of the language practices and the applicability or the relevance of the language learning in the real world.

\section{CONCEPTUAL FRAMEWORK}

Fig. 1 presents the correlation of the predictor variables and the dependent variable.

\begin{tabular}{|c|c|}
\hline $\begin{array}{l}\text { 1. Language competence } \\
\text { in the workplace } \\
2 . \quad \text { Language competence } \\
\text { in the classroom }\end{array}$ & $\begin{array}{c}\text { Level of } \\
\text { International } \\
\text { Competitiveness }\end{array}$ \\
\hline
\end{tabular}

Fig. 1. The Conceptual Model of the Study

\section{Methodology}

The Pearson $r$ correlation analysis using 2-tailed test evaluated the statistical evidence of the strength and linear relationship between language competence of the graduating students in the classroom and in the industry, and the international competitiveness of the graduates. Using a developed questionnaire, the language competence of the BA Broadcasting students in the industry during the internship program of the graduating students in the academic year 2015-2016, a self-assessment procedure was done to describe their performance during the internship training. The internship evaluation form was patterned after the existing guidelines prepared by the Kapisanan ng mga Broadkaster sa Pilipinas and the Philippine Association of Communication Educator's (KBP-PACE)Foundation. The evaluation form expressed in the holistic approach is designed specifically to describe the language competence in the industry. Likewise, the grade point average of the respondents in the English field of study was collected from the registrar's office to describe the language competence in the classroom. Importantly, to identify the level of international competitiveness of the graduates of batch 2015-2016, the overall grade point average of all the respondents were collected.

\section{RESUlts AND DisCUSSION}

Table 1 presents the correlation of language competence and international competitiveness.

Table 1. CORRELATION OF LANGUAGE COMPETENCE AND INTERNATIONAL COMPETITIVENESS

\begin{tabular}{c|c|c}
\hline \hline \multicolumn{2}{c|}{} & $\begin{array}{c}\text { Level of International } \\
\text { Competitiveness }\end{array}$ \\
\hline language & Pearson Correlation & $.693^{* *}$ \\
\cline { 2 - 3 } & Sig. (2-tailed) & .000 \\
\cline { 2 - 3 } & $\mathrm{N}$ & 127 \\
\hline \hline
\end{tabular}

**. Correlation is significant at the 0.01 level (2-tailed).

The Sig. (2-Tailed) value in the preceding table is 
at .693, which means that the value is less than .05. Statistics ruled that when the Pearson $r$ is close to one, this means that there is a strong relationship between the two variables. From the recorded data, it can be subsumed that there is a positive/direct relationship between language competence in the classroom and in the industry of the graduating students and the level of international competitiveness of the graduates. This means that there is a strong relationship between the predictor variables and the dependent variable. Conversely, this means that changes in one variable strongly correlate with the changes in the second variable. Illustratively, a decrease in the language competence is a decline in the level of international competitiveness of the graduates; an increase in the language competence is a rise in the level of international competitiveness. Specifically, this means that $1 \%$ increase in the language competence in the classroom and in the industry means $1 \%$ increase in the international competitiveness of graduates.

\section{Conclusion}

The provisions of CMO No.20, s.2009, s.4.1, on expected career paths of graduates of BA Broadcasting clearly demand an in-depth knowledge in the specialized subjects to become competitive in the field of broadcasting. Since this study proved that language competence is directly and positively correlated to the level of competitiveness of graduates, therefore, the precise distinction between the comparability or the impact of the language practices and the applicability or the relevance of the language learning in the real world of the broadcasting language needs to be clearly defined in terms of the expected competencies from graduates. Further, careful evaluation of the expected professions of broadcasting graduates reveals the need for an extensive and intensive training in journalism. This observation on the other hand validates the direct and positive correlation of language competence and international competitiveness.

\section{RECOMMENDATIONS}

Broadcasting technology has been proven to have affected the efficiency of interconnection of topologies, algorithms, information exchange between nodes in the network [4] therefore, the revision of $\mathrm{BA}$ Broadcasting to $\mathrm{BA}$ Broadcast Journalism anchored in research writing is highly recommended for graduates to be competitive. Graduates are most likely to be more employable if they have deep orientation in journalism and in research writing, since broadcast technology is information marketing, then, the training should not just be focused on requisites of broadcasting but on journalism as well, as described in the policy.

Broadcasting technology is a determinant of change [2] and agent of change (www.weforum.org), therefore, a systemic approach to the program revision should be applied to meet the constantly changing world. This dilemma is addressed with investment on language skills that enable competitiveness (ec.europa.eu) modernization of education [5] strong link between language and employability in globalized competitiveness [6]. The trainees should be competent and proficient in the language in the profession to be competitive.

The curriculum should provide a ladderized program that offers Broadcast Journalist Technician (2 years), Broadcast Journalist Assistant (3 years), and Broadcast Technician Specialist (4 years). The ladderized program will refine the attributes of the graduates which will help develop experts in the field.

The program needs an installation of campus broadcasting that will facilitate the needed simulated trainings of the students to enhance competence in broadcasting language; encourage the involvement of the community in determining their needs and interests; and promote collaboration in multilateral disciplines in the university. This campus broadcasting enhances community development using instruction, education, and interdependence.

The international competitiveness of any education program is dependent on competence and performance which demand careful planning, effective program implementation, appropriate learning opportunities, and fitted evaluation scheme. Hence, international competitiveness requires a standardized learning opportunities for the students.

\section{REFERENCES}

[1] Song, JB. (2016). Safe Broadcasting of Television Program.

[2] Lau, H. Y. (2015). Cultivation Effects of Television Broadcasting and Online Media. In New Media, Knowledge Practices and Multiliteracies (pp. 13-21). Springer, Singapore.

[3] Hoeg, W., \& Lauterbach, T. (Eds.). (2009). Digital audio broadcasting: principles and applications of $\mathrm{DAB}, \mathrm{DAB}+$ and DMB. John Wiley \& Sons.

[4] Grigoryan, H. (2013). Problems related to broadcasting in graphs (Doctoral dissertation, Concordia University). Retrieved from http://www.spectrum.library.concordia.ca

[5] Sedivy, J. (2015). Research on Language Competence in Doctoral Studies at Universities in Czech Republic. Procedia-Social and Behavioral Sciences, 191, 1991-1995.

[6] Carter, B. A. (2015). Language and competitiveness in Trinidad and Tobago: Taking stock.

[7] Community Radio Broadcasting Code of Practice (2008). Retrieved from http://www.989fm.com.au 
[8] CMO No.20,s.(2006). Retrieved from http://www.ched.gov.ph

[9] Effects of the European Economy of Shortages of Foreign Language Skill in Enterprise. 2006. Retrieved from http://ec.europa.eu

[10] Film, Television, and New Broadcast Media.2016. http://www.fass.kingston.ac.uk

[11] Pew research center. (2015). State of the news media. Retrieved from http://www.newsgeneration.com

[12] The Cultivation of Effects of TV Broadcasting and online Media. Retrieved from http://www.springer.com

[13] Greenberg, A. D., \& Zanetis, J. (2012). The impact of broadcast and streaming video in education. Cisco: Wainhouse Research, 75

[14] UK Attitude to broadcast media. 2016. Retrieved from http://www.ofcom.org.uk 